\title{
Yin and Yang: CCN3 inhibits the pro-fibrotic effects of CCN2
}

\author{
Andrew Leask
}

Received: 8 May 2009 / Accepted: 14 May 2009 /Published online: 29 May 2009

(C) The Author(s) 2009. This article is published with open access at Springerlink.com

\begin{abstract}
Fibrotic disease is a significant cause of mortality. CCN2 (connective tissue growth factor [CTGF]), a member of the $\mathrm{CCN}$ family of matricellular proteins, plays a significant role in driving the fibrogenic effects of cytokines such as transforming growth factor $\beta$ (TGF $\beta)$. It has been proposed that other members of the CCN family can either promote or antagonize the action of CCN2, depending on the context. A recent elegant study published by Bruce Riser and colleagues (Am J Pathol. 174:1725-34, 2009) illustrates that CCN3 (nov) antagonizes the fibrogenic effects of CCN2. This paper, the subject of this commentary, raises the intriguing possibility that $\mathrm{CCN} 3$ may be used as a novel anti-fibrotic therapy.
\end{abstract}

Keywords CTGF $\cdot \mathrm{CCN} 2 \cdot$ nov fibrosis

Fibrotic disease is a significant cause of mortality, and contributes substantially to the global health care costs. Although fibrosis is believed to arise due to the excessive action of fibrogenic cytokines (Krieg et al. 2007), there is no effective treatment. Owing to its ability to promote TGF $\beta$ signaling and fibroblast activation (Grotendorst 1997; Shi-wen et al. 2006; Kennedy et al. 2007) and its overexpression in a wide variety of fibrotic diseases, CCN2 is considered to represent a novel target for anti-fibrotic drug intervention (Blom et al. 2002; Leask et al. 2009).

A. Leask $(\bowtie)$

Canadian Institutes of Health Research Group in Skeletal

Development and Remodeling, Division of Oral Biology

and Department of Physiology and Pharmacology, Schulich

School of Medicine \& Dentistry, University of Western Ontario,

London, ON N6A 5C1, Canada

e-mail: andrew.leask@schulich.uwo.ca
CCN2, a cysteine-rich secretory protein of 36 to $38 \mathrm{kDa}$, has four distinct modules which are shared by most other members of the $\mathrm{CCN}$ family of matricellular proteins (Leask and Abraham 2006). How these proteins influence such a range of functions remains incompletely understood but is likely related this modular nature and a complex array of intra- and inter-molecular interactions with a variety of regulatory proteins and ligands (including cell surface integrins), which are likely to differ among the different CCN proteins (Holbourn et al. 2008). For example, it has long been recognized that CCN1 (CYR61) and CCN2 promote, whereas CCN3 suppresses, cancer cell growth (Perbal 2001). These results raise the possibility that $\mathrm{CCN} 3$ may act to prevent the pathological actions of $\mathrm{CCN} 1$ or $\mathrm{CCN} 2$.

In a recent report, Riser and colleagues (2009) show that, in cultured kidney mesangial cells, CCN3 is normally expressed. TGF- $\beta$ reduces $\mathrm{CCN} 3$ expression but increases $\mathrm{CCN} 2$ and collagen type I expression. Addition of CCN3 or $\mathrm{CCN} 3$ overexpression caused down-regulation of CCN2 and collagen type I. The action of $\mathrm{CCN} 3$ did not depend on cell proliferation or on Smad signaling. CCN3 acted on the type I collagen minimal promoter.

The mechanism underlying $\mathrm{CCN} 3$ action was not identified, but could arise due to the engagement of different integrins resulting in the activation of different non-Smad signaling pathways (e.g., p38, JNK, ERK) (Chen et al. 2007), which are known to affect fibrotic responses (Leask and Abraham 2004). Alternatively, different extracellular ligands may be recruited to the cell surface in the presence of CCN2 alone versus the presence of $\mathrm{CCN} 2$ together with $\mathrm{CCN} 3$ (Perbal 2004). Identification of the precise elements in the type I collagen promoter which respond to CCN3 would be extremely informative. Nonetheless, these data support the idea that the different combinations of $\mathrm{CCN}$ proteins present 
in one locale can result in divergent biological effects and, moreover, that CCN3 may represent a novel, biological antifibrotic treatment.

Open Access This article is distributed under the terms of the Creative Commons Attribution Noncommercial License which permits any noncommercial use, distribution, and reproduction in any medium, provided the original author(s) and source are credited.

\section{References}

Blom IE, Goldschmeding R, Leask A (2002) Gene regulation of CTGF: new targets for antifibrotic therapy? Matrix Biol 21:473482. doi:10.1016/S0945-053X(02)00055-0

Chen CC, Young JL, Monzon RI, Chen N, Todorović V, Lau LF (2007) Cytotoxicity of TNFalpha is regulated by integrinmediated matrix signaling. EMBO J 26:1257-1267. doi:10.1038/sj.emboj.7601596

Grotendorst GR (1997) Connective tissue growth factor: a mediator of TGF-beta action on fibroblasts. Cytokine Growth Factor Rev 8:171-179. doi:10.1016/S1359-6101(97)00010-5

Holbourn KP, Acharya KR, Perbal B (2008) The CCN family of proteins: structure-function relationships. Trends Biochem Sci 33:461-473. doi:10.1016/j.tibs.2008.07.006
Kennedy L, Liu S, Shi-Wen X, Chen Y, Eastwood M, Sabetkar M, Carter DE, Lyons KM, Black CM, Abraham DJ, Leask A (2007) $\mathrm{CCN} 2$ is necessary for the function of mouse embryonic fibroblasts. Exp Cell Res 313:952-964. doi:10.1016/j. yexcr.2006.12.006

Krieg T, Abraham D, Lafyatis R (2007) Fibrosis in connective tissue disease: the role of the myofibroblast and fibroblast-epithelial cell interactions. Arthritis Res Ther 9(Suppl 2):S4. doi:10.1186/ ar2188

Leask A, Abraham DJ (2004) The control of TGFb signaling in wound healing and fibrosis. FASEB J. 18:816-27

Leask A, Abraham DJ (2006) All in the CCN family: essential matricellular signaling modulators emerge from the bunker. J Cell Sci 119:4803-4810. doi:10.1242/jcs.03270

Leask A, Parapuram SK, Shiwen X, Abraham DJ (2009) Connective tissue growth factor (CTGF, CCN2) gene expression: a potent clinical marker of fibroproliferative disease. J Cell Commun Signal., epub

Perbal B (2001) NOV (nephroblastoma overexpressed) and the CCN family of genes: structural and functional issues. Mol Pathol 54:57-79. doi: $10.1136 / \mathrm{mp}$. 54.2.57

Perbal B (2004) CCN proteins: multifunctional signalling regulators. Lancet 363:62-64. doi:10.1016/S0140-6736(03)15172-0

Shi-wen X, Stanton LA, Kennedy L, Pala D, Chen Y, Howat SL, Renzoni EA, Carter DE, Bou-Gharios G, Stratton RJ, Pearson JD, Beier F, Lyons KM, Black CM, Abraham DJ, Leask A (2006) CCN2 is necessary for adhesive responses to transforming growth factor-betal in embryonic fibroblasts. J Biol Chem 281:10715-10726. doi:10.1074/jbc.M511343200 